\title{
MATRIX SUPPORT, INDIVIDUAL THERAPEUTIC PROJECT AND PRODUTION IN MENTAL HEALTH CARE ${ }^{1}$
}

\author{
Maria Salete Bessa Jorge ${ }^{2}$, Alexandre Melo Diniz ${ }^{3}$, Leilson Lira de Lima4, Jardeliny Corrêa da Penha ${ }^{5}$
}

\footnotetext{
${ }^{1}$ Research related to the dissertation - Projeto terapêutico singular de usuários da atenção básica: resolubilidade, corresponsabilização, autonomia e cuidados, presented to Academic Master's Program in Public Health, Universidade Estadual do Ceará (UECE) in 2012.

2 Ph.D. in Nursing. Full Professor at the Undergraduate Nursing and Medical Courses of UECE. Fortaleza, Ceará, Brazil. E-mail: maria.salete.jorge@gmail.com

${ }^{3}$ Master's Student on the Academic Master's Program in Public Health of UECE. Fortaleza, Ceará, Brazil. E-mail: amd_psi@ yahoo.com.br

${ }^{4}$ Ph.D. Student on the Graduate Program of Clinical Care in Nursing and Health of UECE. Substitute Professor at the Undergraduate Medical Course of UECE. Fortaleza, Ceará, Brazil. E-mail: leilson.lira@yahoo.com.br

${ }^{5}$ Master's Student on the Graduate Program of Clinical Care in Nursing and Health of UECE. Fortaleza, Ceará, Brazil. E-mail: deinhapenha@hotmail.com
}

\begin{abstract}
The study aimed to understand how to conform the Support Matrix and Individual Therapeutic Project and its relation with the production of mental health care. This is qualitative research conducted in Fortaleza-CE, Center for Psychosocial Care and Center for Family Health. 17 people participated, between professionals and patients. It was used as for dates collecting semi-structured and systematic observation. The findings were analyzed by narrative analysis, grounded theory by Ricoeur. The results reveal themselves excessive referrals, medical-centered, dependence Health Center to support the specialized care, deficiency of physical space, network disconnection, outsourcing and professional unpreparedness of the Health Center as the production difficulties of care. The Support Matrix and Individual Therapeutic Project therefore happen in everyday services, but with difficulties that affect the organization and production of care.
\end{abstract}

DESCRIPTORS: Health mental. Primary health care. Mental health services.

\section{APOIO MATRICIAL, PROJETO TERAPÊUTICO SINGULAR E PRODUÇÃO DO CUIDADO EM SAÚDE MENTAL}

RESUMO: O estudo objetivou compreender como se conformam o apoio matricial, projeto terapêutico singular, e sua interface com a produção do cuidado em saúde mental. Trata-se de uma investigação qualitativa, realizada em Fortaleza-CE, no Centro de Atenção Psicossocial e no Centro de Saúde da Família. Participaram 17 sujeitos, entre profissionais e usuários. Utilizou-se a entrevista semiestruturada e a observação sistemática. A análise envolveu compreensão de narrativas, embasada pela teoria de Ricoeur. Os resultados evidenciaram o acolhimento, o vínculo e a corresponsabilização no cotidiano assistencial, promovendo cuidado. Desvelaramse, contudo, excessivos encaminhamentos, atendimento médico-centrado, dependência do Centro de Saúde ao suporte da atenção especializada, deficiência de espaço físico, desarticulação da rede, terceirização e despreparo dos profissionais do Centro de Saúde, como dificuldades com a produção do cuidado. $\mathrm{O}$ apoio matricial e o projeto terapêutico singular, portanto, acontecem no cotidiano dos serviços, porém com dificuldades que incidem na organização e produção do cuidado.

DESCRITORES: Saúde mental. Atenção primária à saúde. Serviços de saúde mental.

\section{APOYO MATRICIAL, PLAN TERAPÉUTICO SINGULAR Y PRODUCCIÓN DEL CUIDADO EN SALUD MENTAL}

RESUMEN: La investigación objetivó comprender el Apoyo Matricial y Plan Terapéutico Singular y su relación con la producción del cuidado en salud mental. Se trata de investigación cualitativa, en la ciudad de Fortaleza-CE, Centro de Atención Psicosocial y el Centro de Salud de la Familia. 17 sujetos participaron, profesionales y usuarios. Se utilizó como técnica a la entrevista semiestructurada y observación sistemática. Los datos se analizaron por análisis de narrativas, basada en la teoría de Ricoeur. Los resultados revelaron remisiones excesivas, atención centrada en médico, dependencia del Centro de Salud al apoyo de la atención especializada, desconexión de la red, vínculos de empleo frágil y falta de preparo de los profesionales del CSF como dificultades a la producción del cuidado. El Apoyo Matricial y el Plan Terapéutico Singular ocurren en el cotidiano de los servicios con dificultades que afectan a la organización y producción del cuidado. DESCRIPTORES: Salud mental. Atención primaria de salud. Servicios de salud mental. 


\section{INTRODUCTION}

The Family Health Strategy (FHS) represents advances in the consolidation of the Brazilian Psychiatric Reform and, consequently, in the reorientation of services and practices for comprehensive and effective care in mental health. Among the aspects that characterize these advances, we can mention: care actions in home territory, ease in the establishment of bonding between the staff and the user, acceptance, accessibility, continued treatment and development of collective actions, such as cultural, educational, participative and political leadership initiatives. ${ }^{1}$

Thus, the discussion on the progress of public policies on mental health care focuses on the articulation of replacement psychiatric hospital services, such as the Psychosocial Care Centers (CAPS, as per its acronym in Portuguese) and Therapeutic Residences (TR), with the assistance network for Primary Health Care (PHC) services, coordinated by the FHS. ${ }^{2}$ This articulation should therefore comprise spaces where ways of thinking and acting in mental health can be expressed, consistent with the valuation of the subject with mental illness, their context of life and their demands and needs.

Consequently, the Support Matrix (SM) constitutes an attempt to consolidate mental health care in PHC and enhance the role of FHS professionals and users. It seeks to ensure a specialized rearguard, by using the CAPS teams, for direct assistance to the user, as well as providing technical and pedagogical support to FHS professionals, equipping them for the proper care of that demand. Furthermore, the SM seeks to increase the degree of solvability of mental health actions, proposing a reformulation in the mode of organization of services and the horizontal relationships between the CAPS team (specialists) and the FHS team, with an interdisciplinary perspective. ${ }^{3}$

This organizational arrangement provides that each professional, or interdisciplinary team, is a certain reference for the number of users, taking responsibility for the development, implementation and evaluation of a Singular Therapeutic Project (STP), developed jointly among staff, patients and families. Therefore, it aims to create a shared plan, which assumes user monitoring, considering social, family and psychological aspects. ${ }^{3-4}$

The STP is a case discussion team, a group which incorporates an interdisciplinary concept and which gathers the contribution of various specializations and distinct professions. ${ }^{5}$ In fact, what is being sought with the SM and the treatment plan is the comprehensive care of the user and their demand, as soon as they enter PHC and throughout their journey within the care network.

Thus, the STP is developed, taking into account the health needs of each user, their way of understanding life, their subjectivities and singularities. Through horizontal interaction of the agents involved in care (workers and users) they should be underpinned with the technologies of relationships, such as acceptance, listening and bonding, proposing new ways of mental health care at different levels of service. ${ }^{6}$

It is noteworthy that in many countries there are constant concerns and several strategies to facilitate primary mental health care. International studies $^{7-8}$ show that integration policies between PHC and mental health, in line with the training of PHC health teams, increase availability of psychotropic medicines in primary health care and mental health care activities in the community, provide a reduction in admissions to psychiatric hospitals, induce reintegration into society and question processes of stigmatization. ${ }^{8}$

In Brazil, the literature outlines important advances in mental health care in PHC, through the SM. However, many challenges still remain. Among these advances, we can mention: establishing a link between users and teams and between the CAPS and FHS teams, ${ }^{9}$ deconstitution of the logic for referrals and, through collective development, facilitating the co-responsibility and continuous assessment in the treatment of users. ${ }^{10}$ As challenges, the poor integration between the networks of mental health care and $\mathrm{PHC}^{11}$ and poor ability to communicate and listen to the needs in mental health ${ }^{6,12}$ are realities that still hamper the effectiveness of the support matrix strategy.

In line with these findings, there are still difficulties in developing PHC as support in interdisciplinary care, with the appreciation of the subjective dimension and encouraging the participation of the user., ${ }^{4,6}$ Furthermore, the interpersonal relationship between reference staff/ professionals in the articulation of the treatment and identifying patients' needs is referred to as an action focused on the reference professional and not on a relational process. ${ }^{4}$

Nevertheless, the consolidation of the psychosocial care model permeates the recognition of the subjective dimension of the users/family members in developing the treatment plan, and 
in the appreciation of primary mental health care, which can be enabled by the practice of the support matrix and construction of the STP.

Whereas the contributions of these arrangements relate to conducting therapy in mental health not restricted to drugs, but combined with other therapeutic resources such as listening, acceptance, connection and co-responsibility, the question is: how does one conform the SM and STP in the day to day of the FHS and CAPS? In which way, therefore, do they plan the production of mental health care?

Faced with the aspects highlighted and the limited scientific production ${ }^{2,4,9}$ on these strategies and their relationship with the care in PHC, the aim of this article was to understand how the SM and the STP are conformed, and their interface with the production of mental health care. Its object of analysis is the production of care, which occurs by light technologies (acceptance, bonding, co-responsibility and autonomy), relations established between teams, and between them and the users. ${ }^{13}$

\section{METHOD}

This research is qualitative in nature, with an eye to the Phenomenological Hermeneutics. ${ }^{14}$ Therefore, it focuses on the understanding of narratives, seeking to understand the multiplicity of the meanings present in the interviews.

The research was conducted in the city of Fortaleza, Ceará state. Fortaleza is politically and administratively divided into six Regional Executive Secretariats (RES), all responsible for the management of health services in their respective coverage area. The healthcare networks from the setting investigated have Primary Care, with the Family Health Strategy (FHS), as their structural/ organizational axis, and with respect to actions and mental health services, the city has only six type II General Psychosocial Care Centers (General CAPS), one in each executive secretariat; six CAPS for alcohol and other drugs (ad CAPS), one in each region and two child CAPS (i CAPS), installed in RES III and IV. ${ }^{15}$

Thus, the locus of the research was a General Psychosocial Care Center, focused on adults with severe mental illness, and a Family Health Center (FHC) whose actions are organized by the FHS teams. In these FHCs, the SM activities have been performed since their implementation in the municipality, in 2007. Moreover, the mu- nicipal management has incorporated continuing education processes in order to equip teams with $\mathrm{SM}$ practices, mainly providing the FHS professionals with scientific-technical ability to monitor users with an established psycho-pathological condition. ${ }^{15}$

There were 17 participants, divided into four groups: group I - two general CAPS professionals (physician and psychologist); group II - four FHC professionals, members of the FHS (two nurses, a physician, a community health agent (CHA) and a nursing assistant) and group III - three professionals from the Support Center for Family Health (NASF, as per its acronym in Portuguese) (a psychologist, a social worker and an occupational therapist) who provided direct care to users, participating in the SM and worked for over a year; group IV - eight users with demands in mental health, participants in the matrix for over a year.

It is noteworthy that the theoretical-methodological approach of this study allows the establishment of connections among the narratives, the interpretation, the theory and the participants' individual experiences. Thus, the search for an understanding of the relationships between parts of the text and the whole, in a process that permeates from the general to the particular and vice versa, ${ }^{16}$ dispenses the theoretical saturation as a final benchmark for the number of research participants.

Data were collected from June to September of 2012, after the project was sent to the Research Ethics Committee of the Ceará State University, which evaluated the relevance thereof, the research objectives and the risks and/or benefits to which the research participants would be subjected, according to resolution 196/96 of the National Health Council ${ }^{17}$ and provided it with a favorable opinion on April 30, 2012, as per protocol 17963.

In order to preserve the anonymity of participants, the narratives that emerged from the interviews were identified as follows: CAPS health professionals (CAPS physician and CAPS psychologist), FHS professionals (FHS nurse, FHS physician, CHA and FHS nursing assistant), NASF professionals (NASF psychologist, NASF social worker and NASF occupational therapist) and users (User - numbered from 01 to 08 ).

Semi-structured interviews and systematic observation were used as data collection techniques, performing a direct view of the singularities of the support matrix in mental health in the FHS, the development of singular therapeutic project (STP) and the production of mental health 
care (acceptance, connection, co-responsibility and autonomy). The interviews focused on aspects related to the treatment, activities developed by the services, management of the SM and formulation of the STP.

To analyze the findings, we opted for an analysis of the narratives based on Ricoeur's theory ${ }_{1}^{19}$ which states that the analytical process as regards distance, appropriation, explanation and understanding of the experiences takes place in five steps: transcription of the interviews into text; distanciation; superficial interpretation; structural analysis and comprehensive understanding of the text, named in-depth interpretation. ${ }^{18}$

Based on the material comprised of interviews with four groups of participants, we proceeded with an approach to the text through readings between the various narratives in order to establish units of senses and meanings. This process culminated in the preparation of the following themes: "Construction of the singular therapeutic project and support matrix: production of care and integrity of actions in mental health" and "Support matrix, singular therapeutic project, and the obstacles to the production of mental health care," which were interpreted and analyzed in conjunction with the theoretical framework.

\section{RESULTS AND DISCUSSION}

\section{Theme 1 - Construction of the singular therapeutic project and support matrix: production of care and integrity of actions in mental health}

Overall, the narratives reveal that mental health care is marked by the use of light technologies and the effort of teams in articulating mental health actions between departments of primary and specialized health care, as well as seeking support in resources from the FHC territory, such as churches and schools.

The construction of the STP, signed on this modus operandi, focuses on acceptance, listening and bonding which, articulated with the SM, consider the care in primary care as necessary for the production of mental health care.

Light technologies, such as acceptance and bonding, appear as symbols of mental health care and are articulated with the feeling of user satisfaction in relation to the services received. Users return to the relational process established between them and the workers in the therapeutic project, demonstrating the importance that intersubjective relations have in health work.

Considering the complexity involved in mental health problems, their determinants and their influence on biopsychic and social aspects, such devices equip health workers for the therapeutic monitoring of people with mental illness, because they enable comprehensive care, allowing for the appropriation of workers to the living conditions of these users, ensuring access and care in home territory and promoting adherence to the pharmacological and non-pharmacological treatment.

We can observe, therefore, that this organization of actions in mental health broadens the clinical horizon of teams. This broadened clinical horizon is based on light technology and anchored in the articulation of the teams (FHS and CAPS), in addition to recognizing the complexity of the subject in the disease process and understanding the need for clinical interventions agreed upon by professionals during the development of the user's therapeutic project. ${ }^{19}$

This confluence between the use of light technologies and the expansion of the clinical horizon refers to a comprehensive mental health care in the FHS. With this, FHS workers involve themselves in the production of comprehensive care through a broadened clinical horizon, because they consider the subject in its context and singularity, opposed to the biomedical model, which is focused on the illness and fragmented care. ${ }^{19}$ Through light technologies, workers approach the comprehensiveness of care, which reveals and manifests itself, among other devices, by acceptance and connection, co-responsibility and autonomy. ${ }^{20}$

This evidence is supported by the literature. Some authors ${ }^{6,20}$ emphasize that light technologies are fundamental devices for the production of comprehensive mental health care, as they make it easier for the user to stay in the service and, therefore, adhere to treatment. Extended clinical practice and use of light technologies allow thinking about health care in the comprehensiveness of the subject, the environment and relationships, because care is the construct of social, economic, familial, biological, psychological and cultural aspects. ${ }^{6}$ Therefore, becoming involved with the production of comprehensive care means to advance in practices that transform the field of mental health.

The encounter between workers and users, mainstreamed by relational tools, directs health 
care to solvability emanating from actual evocations of subjectivity ${ }^{20}$ and providing satisfaction. Thus, the care produced, in dialog, close to each singularity, allows us to understand the reality, the experience in the micro-political space of each encounter, and enhances the use of light technologies, as well as the management of the extended clinical practice in the FHS to establish actions in mental health closer to everyday use and each subjectivity.

Still as regards satisfaction, some users have shown contentment, in their narratives, of the new possibility to be cared for: receive care at the health center (User 06). Users who abandoned treatment, which was performed at CAPS, return, complainingly, to the monitoring they had received in that service. Medicalization practices, ${ }^{21}$ centered on procedures, prescriptions and with the absence of subjective interactions, demotivated these users from adhering to treatment.

The narrative of one user describes these two moments in his treatment. In allusion to the old treatment, over five years ago (User 08), received at CAPS, it is emphatic in revealing practices centered only on drug prescription, without spaces for dialog, listening and acceptance, and with significant devaluation of the user as the subject of their disease process: the service was as follows: 'what medication do you take ma'am?', I said: this one [...]. So he gave me the prescription, he handed it to me and that was it. I mean to say: oh boy, I'm not going to stay here, the man didn't even look at me (User 08). Users, therefore, reveal their satisfaction with their monitoring in the FHS, emphasizing the bonding and empathy with FHC professionals: so I came here [...] and I identified myself with the professionals (User 08).

One can notice that there is an intense influence of classical psychiatric content in CAPS care. The objective of contemporary psychiatry practices still involves the user to make use of the medication, i.e., these asylum practices continue to occur even in replacement services. Moreover, users are not asked what they think about the treatments they receive or the routines to which they are submitted..$^{22}$ This implies pointing out that there is no actual deinstitutionalization, as this not only refers to the process of dehospitalization, but the deconstitution of concepts and actions of classic psychiatric content. $^{21}$

It is also noteworthy that the monitoring of some users in CAPS, achieved after the implementation of the SM, also fosters satisfaction among these subjects. People with severe mental disorders, formerly excluded from mental health care, came to receive treatment from the CAPS team, articulated with the reference team. Narratives from workers and users, illustrating this evidence relate to a user, resident in the territory covered by the FHS.

Without access to the care and follow-up needed, that user, almost always in crisis, experienced periods of psychiatric hospitalization until being identified in the territory by a $\mathrm{CHA}$ : I was always being hospitalized, then the agent found me and took me to the health center. I was referred to CAPS by the physician from here [FHS]. I went five months without sleeping, just taking the medicine, I was crazy. Not now, now I'm good. I know I ended up with a very severe crisis (User 03); we identified it and we accepted him here at the health center and we referred him to CAPS [...] we are kind of monitoring him. We always ask for help from CAPS for these more serious cases (FHS Nurse).

In light of the foregoing, it can be noted that the health center promotes access to mental health care and still coordinates the therapeutic flow of users with severe mental disorders. This process involves making clinical decisions on the part of the FHS team, passing through qualified listening, in order to identify the severity of the case and the possible need for a resolution at the health center and/ or referral to CAPS. ${ }^{20}$

Moreover, to compose the STP, the teams are articulated to the devices in the territory in order to broaden the potential resolution of clinical mental health cases: there was a support matrix for a girl who had anxiety disorder and complained that she was very much alone, that she was unable to leave the house, then we contacted her school to enter her in activities and we even managed to get her in the church choir [...] (CAPS Psychologist).

Although it is timely, one can note an attempt of intersectoral articulation in mental health care. These results confirm the evidence of other studies $^{7,12}$ that aimed to understand/analyze the development of the singular therapeutic project. In these studies, schools, churches and neighborhood associations were characterized as important spaces for mental health care in the territory. Thus, the welfare services of the Unified Health System (SUS, as per its acronym in Portuguese) should be articulated with such institutions to make integrated operational pacts, ${ }^{12}$ also highlighting the possibility of reducing medicalization processes that still permeate health mental actions. ${ }^{22}$ 
As you can see in this thematic unit, the support matrix and the construction of the STP are essential for care in individual and social situations. FHS is an important device for offering care to users with mental disorders: it promotes equity and access, ensuring therapeutic flows according to the vulnerabilities and strengths of each user and formulating therapeutic plans for each singular situation. ${ }^{11}$

\section{Theme 2 - Support matrix, singular therapeu- tic plan, and the obstacles to the production of mental health care in primary care}

In this thematic unit, the narratives reveal that the SM strategy and the STP conduct, in the setting investigated, have challenges related to the organization of mental health actions, to the attachment to the logic of referrals, centrality on the figure of the physician and dependence on the support of the specialized CAPS team.

Regarding the first aspect, the understanding and interpretation of narratives allow us to analyze the mental health actions at the CAPS and the FHS, as well as the interaction of these two scenarios. Therefore, the everyday noises in the organization of the services, teams, practices and knowledge involved in the SM and in the preparation of the STP are revealed.

The dynamics of the services proves dissonant in the Psychiatric Reform proposals, as regards the need to conduct primary care in mental health. The FHS team reports difficulties in offering, in a continuous manner and with quality, care to users with mental disorders because of the various activities in their everyday life, such as consultations aimed at public health programs: [...] we try to meet this demand [mental health cases], but it's hard [...] the schedule is very full, a lot to attend to, there is hypertensive, prenatal [patients] [...] (FHS Nurse).

In this sense, the narratives, among the four groups, are not identical, because their significance is now structured in care focused on light technologies and sometimes blunts the absence of attitudes in co-responsibility. In fact, the team manages practices of acceptance given some existing clinical mental health cases in the territory, but it is restricted in carrying out screening of cases to, whenever necessary, refer them to the CAPS or just seek information at support matrix meetings on a particular referred user: if the physician thinks that it can be solved here, the patient stays. If they think the patient has a higher-level CAPS profile, they refer him to the CAPS (NASF Psychologist).

Other studies ${ }^{9,12}$ have also shown that, in the approach to cases of mental health at the FHS, the disorders and their severity surround the care, which precedes an order of resolution or referral. In summary, the actions are aimed at maintaining the balance, if the case is mild; or, for referral to the CAPS, for moderate or severe cases, which are then followed up by the reference team.

This understanding that the CAPS should assist users with a severe disorder or when in crisis and then return them to the FHS, to their territory, refers to the asylum model, i.e., offer service within a specific location and then return them to society, while therapeutic intervention in the social context of people has greater effectiveness, with the articulation between these services being, therefore, necessary. ${ }^{12}$

The difficulty, however, in promoting mental health care is also related to the social and political context in which the agents in health practices are involved. Mental health in the environment studied, not differing from other realities, is hampered by the disarticulation of policies aimed at the sector. ${ }^{10}$ This support matrix is very difficult [...], space that we don't have, because we do it in the nurse's room and it gets crowded! (NASF Social worker); It is not the fault of the people who work, no. It is the system itself [...] the professionals at the unit, most of them are outsourced, so we also have this staff turnover (NASF Occupational Therapist).

Therefore, difficulties in carrying out the SM and in building the STP are also related to the deficiency of physical space for meetings to be held, disarticulation of the primary care network and outsourcing of professionals, which induces higher staff turnover, both in the CAPS and in the FHS, reflecting in increased bonding and apprehension of the problems in the territory.

This conjuncture produces obstacles in accomplishing the support matrix strategy. They visualize difficulties in consolidating the psychosocial care model, reflected in the poor articulation of the primary care system and excessive referrals to other services, requiring the involvement of users, managers and health workers in the struggle in defense of the SUS, and with the purpose of transforming public health, especially in the field of mental health. . $^{1023}$

When they experience this reality, workers report a feeling of helplessness and lack of preparation in dealing with clinical mental health cases 
that arrive daily at the service, hindering the actions agreed to in the support matrix: there are cases here of drug addiction, the person is unemployed and gets depressed. [...] there is a lot of this and sometimes it's complicated (FHS Physician). Part of these professionals remains embedded in traditional clinical practices grasped in their training. In the face of social determinants in the health-disease process, to which the enrolled population is subjected, physicians resort to pharmacological therapy as a valuable therapy for the somatization in the social vulnerability of users.

One can also add the difficulty that primary care physicians have in prescribing psychotropic drugs, remaining dependent on the CAPS team. Some cases that were referred over here [CAPS], we could see that they were not patients being assisted at the CAPS. [...] for any doubts, from either the nurse or physician, questions of medication, they sent the patient to the CAPS (CAPS Physician). As one can see, even the disorders classified as "mild", anxiety and depressive episodes, require support so that the necessary medications are prescribed.

While it is possible that the SM refers to the exchange of knowledge (technical and pedagogical support), guidelines between teams and reorientation of previously adopted conduct, ${ }^{3}$ as is the case with prescriptions, investment in the training of mental health professionals of the FHS is considered extremely important. ${ }^{2,4}$ Guided in the theoretical and practical dimension of interventions, the processes of continuing education should be focused on biopsychic and social aspects of the illness, given the biomedical training of primary care professionals, which focuses on biological actions of care and in prescription.

This reality does not apply only to medical professionals. Nurses, for example, report difficulties in producing comprehensive mental health care in the FHS scenario. Care with an emphasis on the biological aspect, or procedures with the body, difficulty in mobilizing skills and knowledge for the conduct of clinical cases in mental health are obstacles in the care process for nurses in primary health care. ${ }^{24}$

These obstacles relate to the formation of the therapeutic project for users with mental disorders. The narratives, according to observations in the field, show that the participation of the user is not effective, i.e., this process does not allow leadership, nor does it promote the autonomy of the subject. In one of the moments of the STP elaboration, we found that the user was invited to be absent from the space for professionals to define their treatment among themselves. They [user] often speak about one thing, but mean another, then we see their need, as soon as they leave, we do the discussion of the therapeutic project, which is that we can be following up for them, even making it easier for them (FHS Nurse).

In this sense, a singular dimension is denied, which is the essence of the therapeutic project. It is with support in the singular that health workers can promote a dialogic and interactive relationship with the user, focusing on their claims, their life experiences and their health-disease process, opinions and needs, thus contributing to the constitution of non-medicalization practices in mental health care.

Regarding the centralization of power, the physician is central in making clinical decisions and managing cases in the SM. Although the teams are also made of other professionals, such as nurses, psychologists, occupational therapists and community health agents, communication and support only occurs by CAPS physician - FHS physician interaction. The monopolization of medical knowledge about a particular case, ${ }^{4}$ therefore, is common practice in the field studied.

This centrality in medical work prevents the construction of integrated therapeutic projects with the core knowledge of the various professionals who make up the teams. Whereas other workers are key in monitoring users with mental disorders and in the formation and conduct of actions in mental health services in the community, such "physician-centered" actions can distance the health center from the population served.

The CHAs, for instance, are subject to singular action, integrating community and health services, as they produce a living and common territory, as well as assuming activities that extrapolate certain actions in the norms of the Ministry of Health or in the management protocols of the health center. They flexibilize tasks in an attempt to respond to the demands of the population. ${ }^{25}$

Several studies ${ }^{2,12,26}$ emphasize the importance of the CHA in mental health care in PHC. Thus, some authors ${ }^{26}$ emphasize the idea that, for interventions to promote mental health and the relationship with family members in the territory, the function of the $\mathrm{CHA}$ is primary and strategic, since it identifies devices in the community and provides a way to listen and embrace the population more closely.

Moreover, the participation of nurses in 
mental health care in PHC is described in the international literature as very promising in fighting disease and adherence to treatment at this level of care. A study ${ }^{7}$ conducted in Canada, whose aim was to evaluate the effectiveness of an intervention program designed for non-psychotic users, showed that the participation of these professionals was critical in increasing bonds and reducing the difficulties faced by users with mental illness.

\section{FINAL CONSIDERATIONS}

In conclusion, we realize that there are many challenges still ahead for mental health care in primary care. However, going beyond a policy for the articulation of services, this strategy happens in everyday services and moves itself in two ways. The first is based on the relation between users and workers, producing care and access to health services. Furthermore, subjects are involved with the daily care routine, which seeks means and strategies to make an effect on the care that is offered in home territory.

There is another revealing movement related to macro-political (policies for the sector) and micro-political (power relations) difficulties, and it concerns organizing strategies such as the support matrix and the singular therapeutic project which, in their theoretical and ideological framework, seek quality and effectiveness of mental health activities. These two movements determine similarities and differences relating to the production of mental health care and the consequent consolidation of the Brazilian Psychiatric Reform.

Among the strategies to be developed, the implementation of permanent education processes with a view to the empowerment of FHS workers to resolve mental health problems and their determinants, encouraging interdisciplinary work, flexibilizing the schedule of care services so that they are given the opportunity to embrace and manage mental health cases and for better structuring health centers, constitute possibilities for organizing and strengthening innovative practices in the field of mental health.

As regards the limits of this study, the possible contributions of the family must be considered in order to obtain diversified reports, because often these individuals actively participate in the care of people with mental disorders, and it is also important to consider their opinions, wishes and desires in the preparation of the therapeutic project. Arising from the results produced here, evaluative studies are needed for the organization of mental health that emphasize care, clinical and management policies, strategies and practices.

\section{REFERENCES}

1. Lancetti A, Amarante PDC. Saúde mental e saúde coletiva. In: Akerman M, Drumond Jr. M, Campos GWS, Carvalho YM, Minayo MCS, organizadores. Tratado de saúde coletiva. $2^{a}$ ed. São Paulo (SP): Hucitec Editora; 2012. p. 615-67.

2. Vecchia MD, Martins STF. Desinstitucionalização dos cuidados a pessoas com transtornos mentais na atenção básica: aportes para implementação das ações. Interface Comunic Saúde Educ. 2009 Jan-Mar; 13(28):151-64.

3. Cunha GT, Campos GWS. Apoio matricial e atenção primária em saúde. Saúde Soc. 2011 Out-Dez; 20(4):961-70.

4. Miranda L, Onocko-Campos RT. Análise do trabalho de referência em Centros de Atenção Psicossocial. Rev Saúde Pública. 2008 Set-Out; 42(5):907-13.

5. Campos GWS. Clínica e saúde coletiva compartilhadas: teoria paideia e reformulação ampliada do trabalho em saúde. In: Akerman M, Drumond Jr. M, Campos GWS, Carvalho YM, Minayo MCS, organizadores. Tratado de saúde coletiva. $2^{\mathrm{a}}$ ed. São Paulo (SP): Hucitec Editora; 2012. p. 41-79.

6. Pinto DM, Jorge MSB, Pinto AGA, Vasconcelos MGF, Cavalcante CM, Flores AZT, et al. Projeto terapêutico singular na produção do cuidado integral: uma construção coletiva. Texto Contexto Enferm. 2011 Jul-Set; 20(3):293-302.

7. Koekkoek B, Van Meijel B, Schene A, Smit A, Kaasenbrood A, Hutschemaekers G. Interpersonal community psychiatric treatment for non-psychotic chronic patients and nurses in outpatient mental health care: a controlled pilot study on feasibility and effects. International Journal of Nursing Studies. 2012 Set-Out; 49(5):549-59.

8. Shim R, Rust G. Primary care, behavioral health and public health: partners in reducing mental health stigma. American J Public Health. 2013 May; 103(5):774-6.

9. Delfini PSS, Reis AOA. Articulação entre serviços públicos de saúde nos cuidados voltados à saúde mental infantojuvenil. Cad Saúde Pública. 2012 Fev; 28(2):357-66.

10. Bezerra E, Dimenstein M. Os CAPS e o trabalho em rede: tecendo o apoio matricial na atenção básica. Psicol Cienc Prof. 2008 Set; 28(3):632-45.

11. Figueredo MD, Onoko-Campos RT. Saúde mental na atenção básica à saúde de Campinas, SP: uma rede ou um emaranhado? Ciênc Saúde Coletiva. 2009 Jan-Fev; 14(1):129-38. 
12. Pinto AGA, Jorge MSB, Vasconcelos MGF, Sampaio JJC, Lima GP, Bastos CC, et al. Apoio matricial como dispositivo do cuidado em saúde mental na atenção primária: olhares múltiplos e dispositivos para resolubilidade. Ciênc Saúde Coletiva. 2012 Jan-Mar; 17(3):653-60.

13. Santos AM, Assis MMA, Rodrigues AAAO, Nascimento MAA, Jorge MSB. Linhas de tensões no processo de acolhimento das equipes de saúde bucal do Programa Saúde da Família: o caso de Alagoinhas, Bahia, Brasil. Cad Saúde Pública. 2007 Jan; 23(1):75-85.

14. Ricoeur P. Do texto à ação: ensaios de hermenêutica II. Porto (PT): Rés-Editora, 1989.

15. Fortaleza. Secretaria Municipal de Saúde de Fortaleza. Relatório de gestão do ano de 2007: saúde, qualidade de vida e a ética do cuidado. Fortaleza (CE): imprensa municipal; 2007.

16. Caprara A, Veras MSC. Hermenêutica e narrativa: a experiência de mães de crianças com epidermólise bolhosa congênita. Interface - Comunic Saúde Educ. 2004-2005 Set-Fev; 9(16):131-46.

17. Ministério da Saúde (BR). Conselho Nacional de Saúde, Comissão Nacional de Ética em Pesquisa. Resolução n. 196 de 10 de outubro de 1996: diretrizes e normas regulamentadoras de pesquisa envolvendo seres humanos. Brasília (DF): MS; 1996.

18. Geanellos R. Exploring Ricouer's hermeneutic theory of interpretation as a method of analysing research texts. Nursing Inquiry. 2000 Jul; 7(2):112-9.

19. Campos GWS. Reflexões sobre a clínica ampliada em equipes de saúde da família. In: Campos GWS.
Saúde Paidéia. $3^{\text {a }}$ ed. São Paulo (SP): Hucitec; 2007. p. 68-75.

20. Jorge MSB, Pinto DM, Quinderé PHD, Pinto AGA, Sousa FSP, Cavalcante CM. Promoção da saúde mental - tecnologias do cuidado: vínculo, acolhimento, co-responsabilização e autonomia. Cien Saude Colet. 2011 Abr-Jun; 16(7):3051-60.

21. Amarante P. Saúde mental e atenção psicossocial. $3^{\mathrm{a}}$ ed. Rio de Janeiro (RJ): Fiocruz; 2011.

22. Reuter C, Peixoto PTCP. Psiquiatria, saúde mental e biopoder: vida, controle, e modulação no contemporâneo. Psicol Estudo. 2009 Abr-Jun; 14(2):267-75.

23. Dimenstein $M$, Severo AK, Brito M, Pimenta AL, Medeiros V, Bezerra E. O apoio matricial em Unidades de Saúde da Família: experimentando inovações em saúde mental. Saúde Soc. 2009 JanMar; 18(1):63-74.

24. Amarante AL, Lepre AS, Gomes JLD, Pereira AV, Dutra VFD. As estratégias dos enfermeiros para o cuidado em saúde mental no Programa Saúde da Família. Texto Contexto Enferm. 2011 Jan-Mar; 20(1):85-93.

25. Rodrigues AAAO, Santos AM, Assis MMA. Agente comunitário de saúde: sujeito da prática em saúde bucal em Alagoinhas, Bahia. Ciên Saude Colet. 2010 Jul-Set; 15(3):907-15.

26. Onocko-Campos RT, Campos GWS, Ferrer AL, Corrêa CRS, Madureira PR, Gama CAP, et al. Avaliação de estratégias inovadoras na organização da atenção primária à saúde. Rev Saúde Pública. 2012 Jan; 46(1):43-50. 